\title{
Water Temperature and Surface Coating Effect on Floatability, Water Absorption and Thickness Swelling of Feed
}

\author{
Eunice Oluwayemisi Adeparusi \\ Department of Fisheries and Aquaculture \\ Federal University of Technology, PMB 704, Akure, Nigeria \\ Tel: 234-80-6722-8308_E-mail: yemisi.eunice@yahoo.com \\ John Alaba Victor Famurewa (Corresponding Author) \\ Department of Food Science and Technology, \\ Federal University of Technology, PMB 704, Akure, Nigeria \\ Tel: 234-80-6296-6602Ｅ-mail: famurewajav@yahoo.com
}

$\begin{array}{lr}\text { Received: May 20, } 2011 & \text { Accepted: June 1, } 2011 \quad \text { Published: December 1, } 2011 \\ \text { doi:10.5539/jas.v3n4p254 } & \text { URL: http://dx.doi.org/10.5539/jas.v3n4p254 }\end{array}$

\begin{abstract}
Ten experimental diets were formulated to meet the $40 \%$ crude protein requirement of the African mudcatfish, Clarias gariepinus. In six of the diets fishmeal served as the main protein source while in the remaining four diets fishmeal was supplemented with either GNC or soybean cake to make isonitrogenous diets. The binding efficiency and some physical properties of diets formulated from each of the five binders: rice bran, brewery distiller grain (BDG), corn bran, soybean and groundnut cake (GNC) were assessed. Any of the other binders was used when either soybean or groundnut cake was not included in the diet. Ingredients were ground and sieved to a particle size of $350 \mu \mathrm{m}$. Three mash conditioning methods: cold water, warm water and cold water with oil coating of pellets were used for mixing each set of ten diets. Physical parameters and binding efficiency were evaluated using floatability, bulk density (BD), water absoption index (WAI) and thickness swelling (TS). Feed with rice bran had the highest floatability with the least BD,WAI and TS. Feed with groundnut had the highest BD, WAI and TS and the least floatability. Mash conditioning with warm water gave a higher floatability over those with cold water but coating of feed with oil after cold water conditioning gave the highest floatability. There is direct relationship between floatability and bulk density (BD) and between floatability and water absorption index (WAI).
\end{abstract}

Keywords: Feed, Binders, Mash conditioning, Oil coating, Floatability

\section{Introduction}

In order to promote good health and attain maxium production, fish has to be fed. Fish nutrition is therefore critical to aquaculture as it represents $40-50 \%$ of the production costs. Feed is a mixture or preparation used to feed livestock. Over $90 \%$ of the feed used for livestock such as sheep, cattle, pigs and poultry is in mash form. A mash is an unpelleted feed mixture while pellet is a feed mixture mehanically forced into a formed shape, usually by compression or extrusion.. Compounded feeds are preferred for fish and shrimp due to the peculiar solvent property of water (FAO, 1990). There has being development and the use of manufactured or artificial diets (formulated feeds) to supplement or to replace natural feeds in the aquaculture industry (FAO, 1997). A wide variety of techniques exist for the manufacture of complete aquaculture feeds ranging from straight mixing/blending to micro encapsulation (New, 1987). Feed formulation and preparation is the process of combining feed ingredients to form a mixture that will meet the specific goals of production. The most desired qualities in pellets are durability, crushing strength, and water resistance. Pellet durability and efficiency can be substantially improved by proper steam conditioning of mash. Steam brings to the surface of pellet mash particles the natural oils and provides lubrication of the pellet die reducing wear on the die and roller assembly and increasing production rates (Behnke, 1996). Different ingredients combinations produce different levels of pellet bouyancy or spatial behaviour within the water column (Strahm and Plattner, 2001). Therefore, it is important to 
have the right ingredients mix for optimum physical characteristics and to avoid wastage due to pellet disintegration in water and nutrient leaching from pellets (Cho, 1980). Clarias gariepinus is one of the most cultured fish in Nigeria and it is circumtropical (Olomola, 1990). In this study the physical properties of feed formulated for the African catfish, Clarias gariepinus, using different binders and three mash conditioning methods were assessed.

\section{Materials and Methods}

\subsection{Diet formulation}

Feed ingredients were purchased at a local feed mill in Akure. The ingredients were ground and sieved to a particle size of $350 \mu \mathrm{m}$. Ten experimental diets were formulated. Five binders: rice bran, brewery distiller grain (BDG), corn bran, soybean and groundnut cake (GNC) (Table 3). These binders were used when either soybean or groundnut cake was not included. In six of the diets fishmeal served as the major protein source while in the remaining four diets fishmeal was supplemented with either GNC or soybean cake (plant protein sources commonly used to reduce cost).

\subsection{Mash conditioning methods}

Three mash conditioning method used for the mixing of ingrediets were:

Method 1: Mash conditioning was done with cold water.

Method 2: Mash conditioning was done using warm water boiled to $50^{\circ} \mathrm{C}$.

Method 3: Mash conditioning was done using cold water but the pellets were coated with oil.

\subsection{Diet Preparation}

For each set of the ten diets, the three mash conditioning were used making a total of thirty diets. Mixing and pelleting of all the diets were done using Hobart (Model A- 2001) pelleting machine.

\subsection{Physical parameters assessed}

The following parameters were assessed on each set of prepared diets: floatability, bulk-density, water absorption index and thickness swelling.

\subsubsection{Floatability}

Floatability was determined as the amount of time (minutes) it takes a pellet sample to flow on $15 \mathrm{~cm}$ water depth. A sample was taken from each diet on each preparatory method and placed at the surface of $15 \mathrm{~cm}$ deep water. The time taken for each sample to sink through the water column was recorded.

\subsubsection{Determination of Bulk Density}

This was calculated using

$$
\text { Bulk Density }=\quad \underline{\mathrm{M}_{2}}-\underline{\mathrm{M}_{1}}
$$

where

$\mathrm{M}_{2}=$ Final mass of sample after soaking $(\mathrm{Kg})$

$\mathrm{M}_{1}=$ Initial weight of sample before being soaking $(\mathrm{Kg})$

$\mathrm{V}=$ Volume of cylinder $\left(\mathrm{cm}^{3}\right)$

\subsubsection{Water Absorption Index}

This was calculated using

where:

$$
\mathrm{WAI} .=\underline{\mathrm{M}}_{\underline{2}}-\frac{\mathrm{M}_{1}}{\mathrm{M}_{1}}
$$

$\mathrm{M}_{2}$ mass of pellet after immersion in water

$\mathrm{M}_{1}$ mass of pellet before immersion in water

\subsubsection{Thickness Strength}

The thickness strength of the diets were calculated using

$$
\text { Thickness Strength }=\underline{\mathrm{T}_{2}-\mathrm{T}_{1}} \frac{\mathrm{T}_{1}}{\mathrm{~T}_{1}}
$$


where,

$\mathrm{T}_{1}=$ the thickness of the pellet sample before immersion $(\mathrm{cm})$

$\mathrm{T}_{2}=$ the thickness of a pellet sample after being immersed in water for three Minutes $(\mathrm{cm})$

\section{Results and Discussion}

The results from this study showed that the ingredients used in feed formulation affect pellet characteristics. Diet with rice bran had the maximum floatability period. This was followed by the diets with brewery distiller waste while diets with groundnut cake had the least. The natural binding qualities of the ingredients used in formulation could be utilized to their fullest extent instead of adding other non-nutrive binding agents. Sinnce rice bran gave the highest floatability, it not only served as source of starch but also as a good binder giving the least WAI and TS. Although both GNC and soyabean have the same quantity of crude protein, their bulk density differs, this affects the floatability of the diets.

Table 2 shows the results obtained from cold water preparatory method. There is direct relationship between floatability and bulk density (BD) and between floatability and water absorption index (WAI). $\mathrm{D}_{1}$ with lowest bulk density $\left(0.44 \mathrm{~g} / \mathrm{cm}^{3}\right)$ has maximum floating time of $4.72 \mathrm{~s}$ and minimum WAI of 0.278 while $\mathrm{D}_{10}$ with highest BD of $0.95 \mathrm{~g} / \mathrm{cm}^{3}$ has the least FT of $2.95 \mathrm{~s}$ and maximum WAI of 0.35 . There is no linear relationship between BD and Thickness Swelling (TS).

Table 3 presents the results obtained from warm water mash conditioning preparatory method. Steam or water is added to increase the moisture content of feed products. The same trend of relationship between floatability and BD that occured with cold water preparation was also observed. In the two methods, both WAI and TS almost yielded the same value for their respective BD. It was noted that warm water enhanced FT (Figure 1). FT at each corresponding BD is higher in warm water treatment than cold water. This may be due to some degree of pre-gelatinization that might have taken place as a result of the higher temperature. Starch possesses a unique ability to lose its crystalline structure and become a viscous gel during processing. This allows it to disperse through and around structures of otherorigins. his loss of crystalinity is known as gelatinization (Svihus et al (2005).The results obtained from analyses of samples prepared from cold water with oil surface coating is shown in Table 4. The results also followed the similar trend with that of ordinary cold water. But floatability was highly enhanced with coating. The corresponding FT to the same BD is higher than in both ordinary cold water and warm water conditioning (Figure 1)

Diets with GNC had the least floatability.This was due to the higher BD of the GNC. The composition of diets affect floatability; it was found out that the higher the bulk density, the lower the floating time. Warm water conditioning resulted in diets with higher floatability than cold water conditioning. The higher the temperature, the higher the galatization and the higher the floatability Tacon (1988) stated that pelleting involve the use of moistened heat and pressure to agglomerate ingredients into larger homogenous particles. Steam or hot water added to the ground feed mixture (mash) during pelleting gelatinize starch which aids in binding ingredients. Generally steam is added to the mash to increase moisture content and temperature.

Oil coating even when pellets were conditioned with cold water gave higher flotability. The amounts of fat, fibre or starch can influence the quality of pelleted feed. Addition of fat to the surface of small particle feeds improves water stability and allows diet to float thereby giving the fish easier access to the feed (Steven, 1987).

Higher floatability is desired in pellets since any finished feed that can seperate into two or more of its component parts through the action of stresses such as dusting, vibration, screening, and generation of static electrical charges is said to be physically unstable. Pellet quality, according to Tacon, (1988), refers to resistance to crumbling and to stability in water. Controlling feed wastage improves feed conversion and reduces nutrient losses. One of the most significant among the abiotic factors affecting fish during growth and development is feed. It directly influences the quality of fish (Kazlauskiene and Vosliene, 2006) Besides feed composition and the balance of its constituents, feed mixing and pelleting makes the unstable dry mash more stable and acceptable. Marcus (2007) reported that pellet quality can be improved significantly with little cost by improving the feed production processes.

\section{Conclusion}

This study has shown that floatability in diets where binders like ricebran, BDG and corn bran were used was higher than those with either soybean or GNC. GNC gave the least floatation. Diets prepared using mash conditioned with warm water float longer than that from cold water. This could be due to the fact that gelatinized starch from cereal grain is an important ingredient allowing the feed particles to expand during extrusion. Although the temperature of mash conditioning affected floatability, surface coating of pellet with oil resulted in 
significant increase in floatability, and reduced WAI thereby keeping the nutrient more intact. Hence, from this study, it has been found out that pellet quality can be improved through feed formulation and mash conditioning.

\section{References}

Behnke, K.C. (1996). Feed manufacturing technology: Current issues and challenges. Animal Feed Science and Technology, vol 62, pp 49-57. An evaluation of wheat as pellet quality enhancer. KSU, Manhattan. http://dx.doi.org/10.1016/S0377-8401(96)01005-X

Cho, C.Y. (1980). Recent advances in diet formulation and nutrition of salmonoid fishes: Type of fat and its quality. Progress report of Conference for Canadian Feed Manufacturers, 1980. University of Guelph, pp 23-27.

FAO. (1997). Julie-Anne.B, Royes and Frank Chapman. Preparing your own fish feeds, http://edis.ifas.ufl.edu/BODY_FA097,10pp

FAO. (1990). Albert G.J. Tacon Fish feed formulation and production Fish feed formulation and reproduction F1:CPR/88/077. Field document 8, 18pp.

Kazlauskiené, N \& Vosyliené. (2006). Physiological state of atlantic salmon (Salmon salar L.) juveniles grown in the Ẑeimena salmon hatchery depending on different feed. ACTA Zoological Lituanica, 2006, vol 1, Numerus, 4:279-285.

Marcus Kenny. (2007). Feed physical quality. Arbor Acres Update:Poultry Nutrition, October, 2007, 6. [Online] Available: www.aviagen.com.

New, M.B. (1987). Feed and feeding of fsih and shrimp. Rome, UNDP/FAO/ ADCP/REP/87/26:275pp.

Olomola, A. (1990). Capture Fisheries and Aquaculture in Nigeria: A comparative economic analysis. African Rural Social Sciences Series Report, 13. pp88.

Svihus, B, Uhien, A \& Harstad, O. (2005). Effect of satarch granule structure, associated components and processing on nutritive value of cereal starch: A review. Animal Feed Science and Technology, vol122, issue3-4, pp303-320. http://dx.doi.org/10.1016/j.anifeedsci.2005.02.025

Steven, C.A. (1987). Starch gelatinization and the influence of particle size, steam, pressure and Die speed on the pelleting process, A Doctor's Dissertation, Kansas state university, MH, Kansas.

Strahm B. and B Plattner. (2001). Put the Right Tools in your Toolbox to ease Aquafeed Extrusion. Feed Management, 52:3 19-22

Tacon, A. G. J. (1988). The nutrition and feeding of farmed fish and shrimp-A training manual 3:Feeding methods. FAO Trust Fund GCP/RLA/075/ITA, Field Document 7/E. Project Support to the Regional Aquaculture Activities for Latin America and the Caribbean, 163pp.

Table 1. Gross composition of diets

\begin{tabular}{|l|l|l|l|l|l|l|l|l|l|l|}
\hline Ingredients & $\mathbf{1}$ & $\mathbf{2}$ & $\mathbf{3}$ & $\mathbf{4}$ & $\mathbf{5}$ & $\mathbf{6}$ & $\mathbf{7}$ & $\mathbf{8}$ & $\mathbf{9}$ & $\mathbf{1 0}$ \\
\hline F.M.(72\%) & 45 & 40 & 45 & 40 & 45 & 40 & 35 & 37.5 & 36.5 & 37.5 \\
\hline Corn & 30 & 35 & 30 & 35 & 30 & 35 & 40 & 37.5 & 38.5 & 37.5 \\
\hline Rice bran & 10 & 10 & - & - & - & - & - & - & - & - \\
\hline BDG & - & - & 10 & 10 & - & - & - & - & - & - \\
\hline Corn Bran & - & - & - & - & 10 & 10 & - & - & - & - \\
\hline Soy Bean (42\%) & - & - & - & - & - & - & 10 & 10 & - & - \\
\hline GNC.(42\%) & - & - & - & - & - & - & - & - & 10 & 10 \\
\hline Cod liver oil & 2 & 2 & 2 & 2 & 2 & 2 & 2 & 2 & 2 & 2 \\
\hline Vit premix & 4.5 & 4.5 & 4.5 & 4.5 & 4.5 & 4.5 & 4.5 & 4.5 & 4.5 & 4.5 \\
\hline Methionine & 1 & 1 & 1 & 1 & 1 & 1 & 1 & 1 & 1 & 1 \\
\hline Lysine & 1 & 1 & 1 & 1 & 1 & 1 & 1 & 1 & 1 & 1 \\
\hline Dicalcium phosphate & 1 & 1 & 1 & 1 & 1 & 1 & 1 & 1 & 1 & 1 \\
\hline Vit.C & 0.5 & 0.5 & 0.5 & 0.5 & 0.5 & 0.5 & 0.5 & 0.5 & 0.5 & 0.5 \\
\hline Groundnut oil & 5 & 5 & 5 & 5 & 5 & 5 & 5 & 5 & 5 & 5 \\
\hline
\end{tabular}


Table 2. Pellet characteristics of diets under cold water treatment

\begin{tabular}{|l|l|l|l|l|}
\hline $\begin{array}{l}\text { Treatment } \\
(\text { Diets })\end{array}$ & $\begin{array}{l}\text { Bulk Density } \\
\left(\mathrm{g} / \mathrm{cm}^{3}\right)\end{array}$ & Floatability (s) & $\begin{array}{l}\text { Thickness } \\
\text { swelling }\end{array}$ & $\begin{array}{l}\text { Water } \\
\text { absorption index }\end{array}$ \\
\hline 1 & $0.44 \pm 0.00^{\mathrm{a}}$ & $4.72 \pm 0.01^{\mathrm{a}}$ & $0.02 \pm 0.00^{\mathrm{a}}$ & $0.27 \pm 0.00^{\mathrm{a}}$ \\
\hline 2 & $0.48 \pm 0.00^{\mathrm{b}}$ & $4.67 \pm 0.02^{\mathrm{b}}$ & $0.02 \pm 0.00^{\mathrm{a}}$ & $0.28 \pm 0.00^{\mathrm{b}}$ \\
\hline 3 & $0.49 \pm 0.00^{\mathrm{b}}$ & $4.10 \pm 0.00^{\mathrm{b}}$ & $0.13 \pm 0.06^{\mathrm{b}}$ & $0.32 \pm 0.00^{\mathrm{c}}$ \\
\hline 4 & $0.50 \pm 0.00^{\mathrm{c}}$ & $4.07 \pm 0.01^{\mathrm{b}}$ & $0.12 \pm 0.00^{\mathrm{bc}}$ & $0.31 \pm 0.00^{\mathrm{d}}$ \\
\hline 5 & $0.51 \pm 0.00^{\mathrm{d}}$ & $4.00 \pm 0.01^{\mathrm{c}}$ & $0.02 \pm 0.00^{\mathrm{a}}$ & $0.33 \pm 0.00^{\mathrm{D}}$ \\
\hline 6 & $0.52 \pm 0.00^{\mathrm{d}}$ & $3.95 \pm 0.04^{\mathrm{c}}$ & $0.02 \pm 0.00^{\mathrm{a}}$ & $0.32 \pm 0.00^{\mathrm{d}}$ \\
\hline 7 & $0.55 \pm 0.00^{\mathrm{e}}$ & $2.94 \pm 0.07^{\mathrm{d}}$ & $0.02 \pm 0.00^{\mathrm{a}}$ & $0.34 \pm 0.00^{\mathrm{e}}$ \\
\hline 8 & $0.56 \pm 0.01^{\mathrm{e}}$ & $3.02 \pm 0.01^{\mathrm{d}}$ & $0.11 \pm 0.12^{\mathrm{ab}}$ & $0.34 \pm 0.00^{\mathrm{e}}$ \\
\hline 9 & $0.56 \pm 0.01^{\mathrm{e}}$ & $2.80 \pm 0.01^{\mathrm{e}}$ & $0.20 \pm 0.00^{\mathrm{c}}$ & $0.34 \pm 0.00^{\mathrm{f}}$ \\
\hline 10 & $0.95 \pm 0.01^{\mathrm{f}}$ & $2.95 \pm 0.01^{\mathrm{e}}$ & $0.02 \pm 0.00^{\mathrm{a}}$ & $0.35 \pm 0.00^{\mathrm{f}}$ \\
\hline
\end{tabular}

The superscript with the same alphabet signifies that there is no significant difference $(\mathrm{P}>0.05)$

Table 3. Pellet characteristics of diets under warm water mash conditioning

\begin{tabular}{|l|l|l|l|l|}
\hline $\begin{array}{l}\text { Treatment } \\
(\text { Diets })\end{array}$ & $\begin{array}{l}\text { Bulk Density } \\
\left(\mathrm{g} / \mathrm{cm}^{3}\right)\end{array}$ & Floatability (s) & $\begin{array}{l}\text { Thickness } \\
\text { swelling }\end{array}$ & $\begin{array}{l}\text { Water absorption } \\
\text { index }\end{array}$ \\
\hline 1 & $0.44 \pm 0.001^{\mathrm{a}}$ & $4.79 \pm 0.01^{\mathrm{e}}$ & $0.02 \pm 0.00^{\mathrm{ab}}$ & $0.27 \pm 0.00^{\mathrm{a}}$ \\
\hline 2 & $0.48 \pm 0.001^{\mathrm{b}}$ & $4.89 \pm 0.00^{\mathrm{e}}$ & $0.02 \pm 0.00^{\mathrm{ab}}$ & $0.29 \pm 0.01^{\mathrm{b}}$ \\
\hline 3 & $0.49 \pm 0.001^{\mathrm{bc}}$ & $4.12 \pm 0.014^{\mathrm{d}}$ & $0.01 \pm 0.00^{\mathrm{ab}}$ & $0.32 \pm 0.00^{\mathrm{c}}$ \\
\hline 4 & $0.50 \pm 0.001^{\mathrm{cd}}$ & $4.10 \pm 0.014^{\mathrm{d}}$ & $0.01 \pm 0.00^{\mathrm{ab}}$ & $0.31 \pm 0.00^{\mathrm{d}}$ \\
\hline 5 & $0.51 \pm 0.001^{\mathrm{de}}$ & $3.88 \pm 0.13^{\mathrm{c}}$ & $0.02 \pm 0.00^{\mathrm{ab}}$ & $0.32 \pm 0.00^{\mathrm{d}}$ \\
\hline 6 & $0.52 \pm 0.001^{\mathrm{e}}$ & $4.00 \pm 0.01^{\mathrm{c}}$ & $0.02 \pm 0.00^{\mathrm{ab}}$ & $0.33 \pm 0.00^{\mathrm{d}}$ \\
\hline 7 & $0.54 \pm 0.02^{\mathrm{f}}$ & $3.01 \pm 0.01^{\mathrm{b}}$ & $0.00 \pm 0.00^{\mathrm{a}}$ & $0.34 \pm 0.00^{\mathrm{e}}$ \\
\hline 8 & $0.55 \pm 0.03^{\mathrm{g}}$ & $2.97 \pm 0.06^{\mathrm{ab}}$ & $0.02 \pm 0.00^{\mathrm{ab}}$ & $0.34 \pm 0.00^{\mathrm{ef}}$ \\
\hline 9 & $0.57 \pm 007^{\mathrm{gh}}$ & $2.91 \pm 0.01^{\mathrm{ab}}$ & $0.11 \pm 0.13^{\mathrm{b}}$ & $0.35 \pm 0.00^{\mathrm{ef}}$ \\
\hline 10 & $0.58 \pm 0.01^{\mathrm{H}}$ & $2.88 \pm 0.06^{\mathrm{a}}$ & $0.02 \pm 0.04^{\mathrm{ab}}$ & $0.32 \pm 0.01^{\mathrm{f}}$ \\
\hline
\end{tabular}

The superscript with the same alphabet signifies that there is no significant difference $(\mathrm{P}>0.05)$

Table 4. Pellet characteristics of diets under oil coated/cold water treatment Parameters

\begin{tabular}{|l|l|l|l|l|}
\hline Treatment (Diets) & Bulk Density $\left(\mathrm{g} / \mathrm{cm}^{3}\right)$ & Floatability $(\mathrm{s})$ & Thickness swelling & Water absorption index \\
\hline 1 & $0.46^{\mathrm{a}} \pm 0.00$ & $6.82^{\mathrm{a}} \pm 0.01$ & $0.02^{\mathrm{ab}} \pm 0.00$ & $0.26^{\mathrm{a}} \pm 0.01$ \\
\hline 2 & $0.49^{\mathrm{b}} \pm 0.00$ & $6.86^{\mathrm{b}} \pm 0.01$ & $0.04^{\mathrm{b}} \pm 0.03$ & $0.27^{\mathrm{ab}} \pm 0.01$ \\
\hline 3 & $0.50^{\mathrm{b}} \pm 0.01$ & $6.01^{\mathrm{c}} \pm 0.01$ & $0.01^{\mathrm{ab}} \pm 0.00$ & $0.32^{\mathrm{c}} \pm 0.01$ \\
\hline 4 & $0.51^{\mathrm{c}} \pm 0.01$ & $6.19^{\mathrm{d}} \pm 0.01$ & $0.01^{\mathrm{a}} \pm 0.00$ & $0.25^{\mathrm{a}} \pm 0.01$ \\
\hline 5 & $0.52^{\mathrm{cd}} \pm 0.30$ & $5.45^{\mathrm{e}} \pm 0.01$ & $0.02^{\mathrm{ab}} \pm 0.00$ & $0.27^{\mathrm{b}} \pm 0.01$ \\
\hline 6 & $0.53^{\mathrm{d}} \pm 0.00$ & $5.99^{\mathrm{f}} \pm 0.01$ & $0.02^{\mathrm{ab}} \pm 0.00$ & $0.28^{\mathrm{b}} \pm 0.01$ \\
\hline 7 & $0.55^{\mathrm{e}} \pm 0.01$ & $4.91^{\mathrm{g}} \pm 0.01$ & $0.02^{\mathrm{ab}} \pm 0.00$ & $0.28^{\mathrm{b}} \pm 0.01$ \\
\hline 8 & $0.58^{\mathrm{f}} \pm 0.01$ & $4.21^{\mathrm{h}} \pm 0.07$ & $0.02^{\mathrm{ab}} \pm 0.00$ & $0.31^{\mathrm{c}} \pm 0.01$ \\
\hline 9 & $0.62^{\mathrm{g}} \pm 0.01$ & $3.98^{\mathrm{i}} \pm 0.01$ & $0.02^{\mathrm{ab}} \pm 0.00$ & $0.31^{\mathrm{c}} \pm 0.01$ \\
\hline 10 & $0.64^{\mathrm{h}} \pm 0.01$ & $3.71^{\mathrm{j}} \pm 0.02$ & $0.02^{\mathrm{ab}} \pm 0.00$ & $0.28^{\mathrm{c}} \pm 0.01$ \\
\hline
\end{tabular}




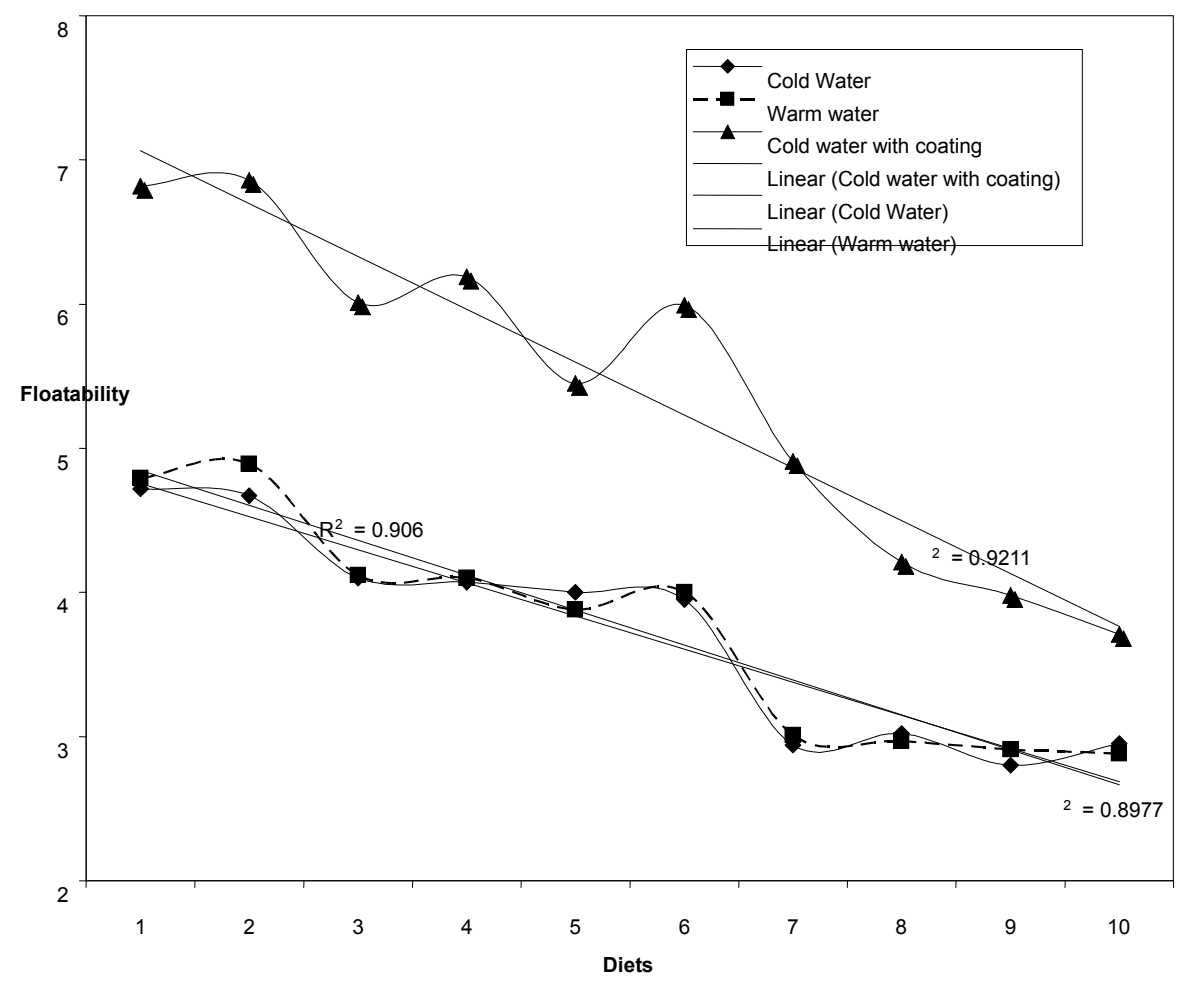

Figure 1. Floatability of the prepared diets

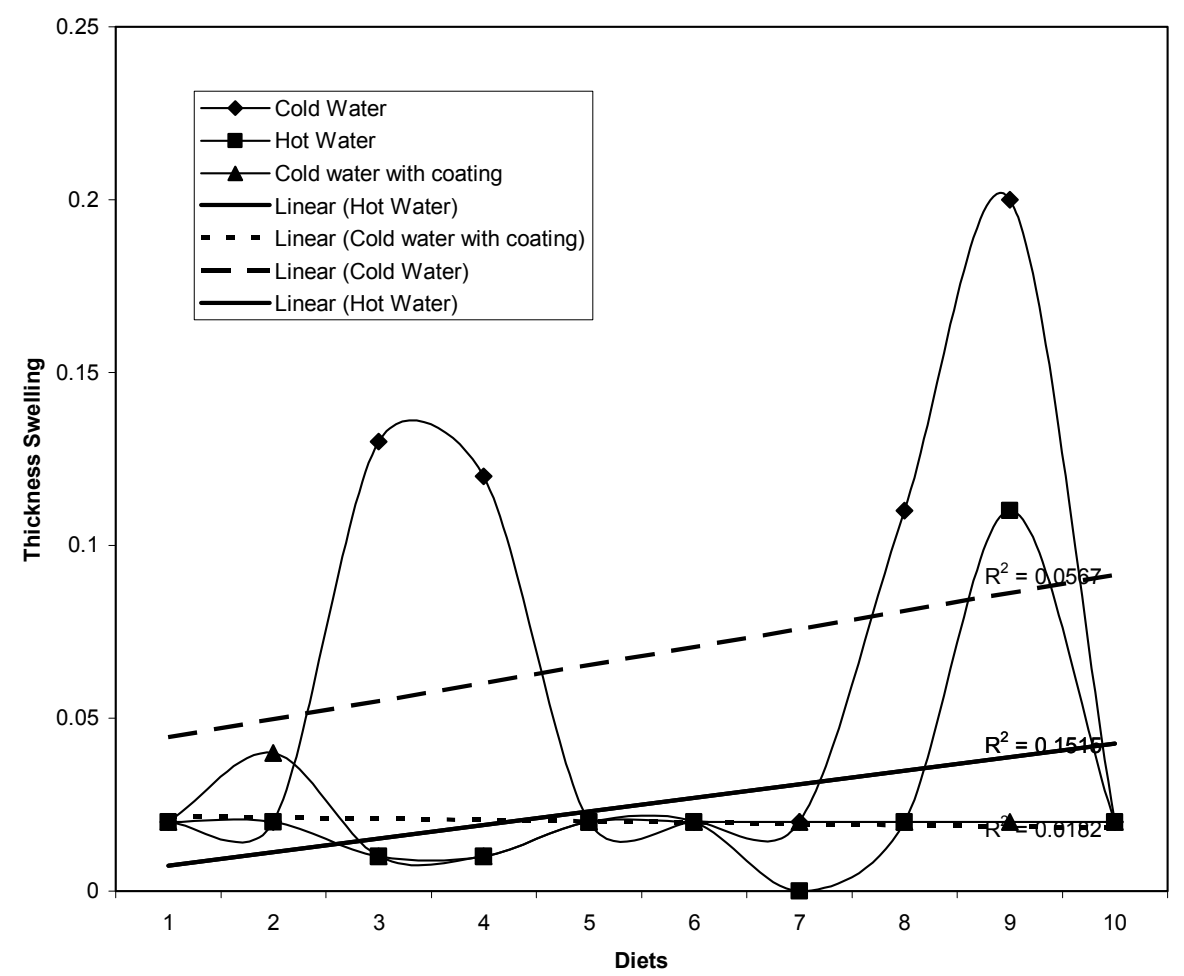

Figure 2. Thickness Swelling of the prepared diets 


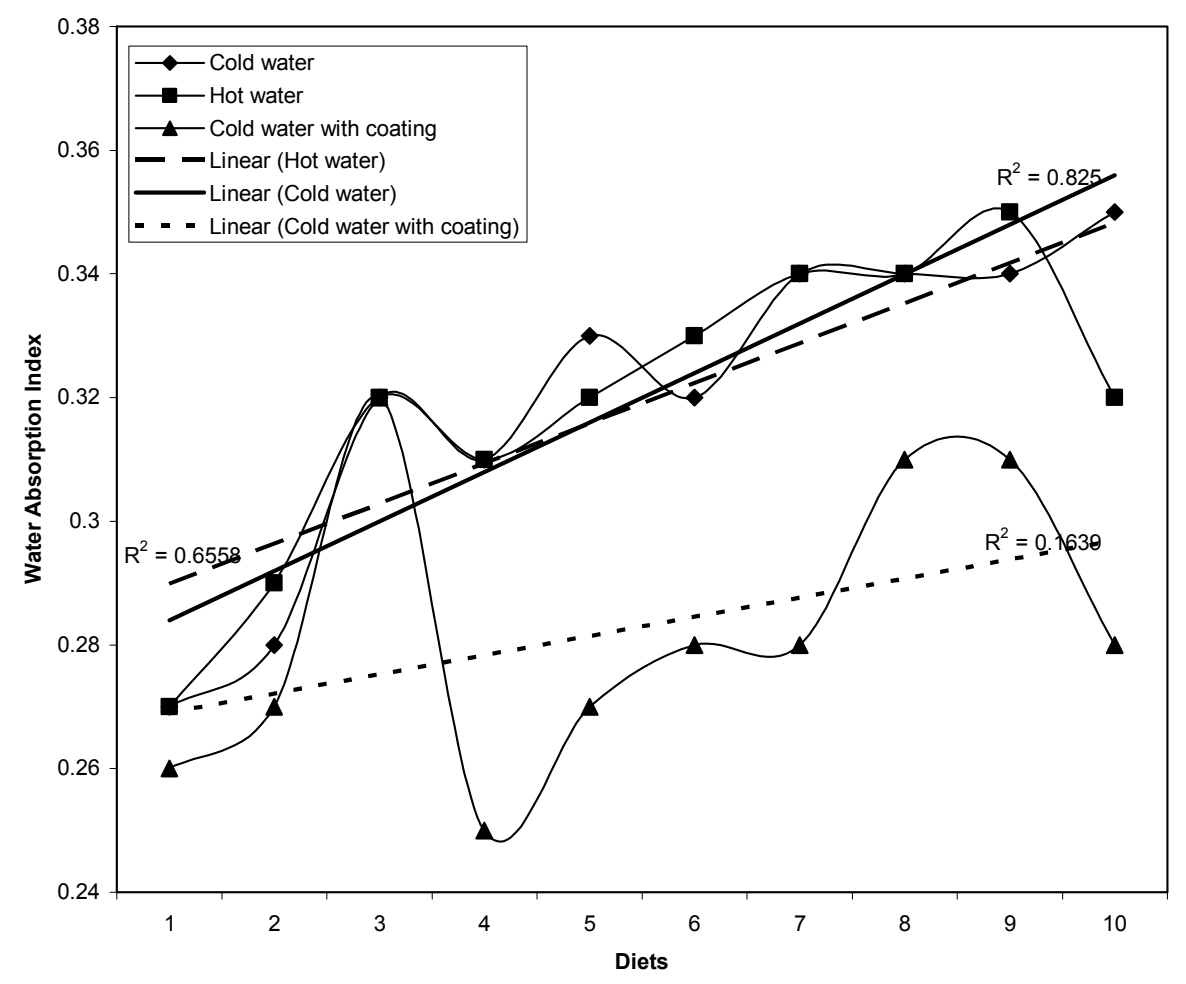

Figure 3. Water Absorption Index of the prepared diets 